\title{
Perancangan Sistem Tata Udara Ditinjau dari Aspek Energi dan Biaya pada Bangunan Hotel di Semarang
}

\author{
Agus Marjianto', Dave Mangindaan ${ }^{2}$ \\ ${ }^{1,2}$ Professional Engineer Program Department, Faculty of Engineering, \\ Bina Nusantara University, \\ Jakarta, Indonesia 11480 \\ agus.marjianto@binus.ac.id; \\ dmangindaan@binus.edu
}

\begin{abstract}
Design of air conditioning system based on the energy and costs aspect of hotel buildings in Semarang] Indonesia's economic growth has been above 5\% for the past few years. Tourism industry is one of the sectors that shows a significant progress. The improvement in tourism industry has to be supported with good hospitality industry as well. Air conditioning system is one of the main utilities in a hotel building. The design of the air conditioning system for a hotel building must pay close attention to the thermal comfort factor for the guests, safety factor, and energy and cost efficiency aspect of it. Air conditioning system design consists of cooling load calculation for the hotel, air conditioning system selection, energy and cost calculation using the life cycle cost analysis. The maximum cooling load in this hotel is $3.279 \mathrm{~kW}$. From that cooling load, three alternative systems are being considered, which are the central air conditioning system using chiller machine that has constant flowrate, the central air conditioning system using chiller machine that has variable flowrate, and the split air conditioning system using VRF machine. Energy analysis and life cycle cost analysis for 20 years was performed to be able to decide the best system. From that energy and cost analysis it can be concluded that the second alternative, which is three units of chiller with variable discharge with a capacity of 1,100 kW for each chiller, is the best system for the hotel. This system has an energy consumption intensity value of $118 \mathrm{kWh} / \mathrm{m}^{2}$ per year and total cost of $R p$. 87,707,416,390 for a period of 20 years.
\end{abstract}

Keywords: Hotel; cooling load; chiller with variable flowrate; energy; cost.

Abstrak - Pertumbuhan ekonomi di Indonesia menunjukkan angka di atas 5\% selama beberapa tahun terakhir.Industri pariwisata di Indonesia merupakan salah satu bidang yang sangat baik perkembangannya. Peningkatan tersebut harus diimbangi dengan adanya akomodasi perhotelan yang baik. Sistem tata udara merupakan salah satu utilitas yang utama pada bangunan hotel. Perancangan sistem tata udara pada bangunan hotel harus memenuhi faktor kenyamanan termal buat penghuninya, aman dan efisien dari aspek energi dan biaya. Perancangan sistem tata udara ini terdiri dari perhitungan beban pendinginan hotel, pemilihan sistem tata udara, perhitungan energi dan biaya dengan analisis life cycle cost. Beban pendinginan maksimum yang terjadi pada hotel ini sebesar $3.279 \mathrm{~kW}$. Dari beban pendinginan tersebut, dipilih tiga alternatif sistem tata udara yaitu sistem tata udara sentral menggunakan mesin chiller dengan debit konstan, sistem tata udara sentral dengan mesin chiller debit berubah, dan sistem tata udara terpisah dengan mesin VRF. Analisis energi dan life cycle cost selama 20 tahun dilakukan untuk menentukan pilihan terbaik. Dari hasil perhitungan energi dan biaya tersebut alternatif kedua merupakan pilihan terbaik, tiga unit chiller debit berubah dengan kapasitas masing-masing chiller adalah $1.100 \mathrm{~kW}$, memiliki nilai IKE $118 \mathrm{kWh} / \mathrm{m}^{2}$ tahun, dan biaya total sebesar Rp. 87.707.416.390,00 untuk jangka waktu 20 tahun.

Kata kunci: Hotel; beban pendinginan; chiller dengan debit berubah; energi; biaya.

\section{PENDAHULUAN}

Pemilihan sistem tata udara yang mempunyai nilai efisiensi yang tinggi dilihat dari aspek energi dan biaya merupakan hal yang sangat penting pada bangunan hotel, yang akan mengurangi biaya penggunaan energi. Dengan pengurangan penggunaan energi yang dibutuhkan secara tidak langsung akan mengurangi jumlah $\mathrm{CO}_{2}$ yang dihasilkan dari produksi energi fosil. Dengan mengurangi jumlah produksi $\mathrm{CO}_{2}$ tersebut secara tidak langsung akan memberikan kontribusi ke lingkungan dengan mengurangi polusi udara.

Oleh karena itu, perancangan bangunan hotel ini 
dengan membuat beberapa alternatif sistem tata udara yang biasa digunakan pada bangunan hotel, akan dilakukan studi dari aspek energi maupun biaya untuk mendapatkan sistem tata udara yang optimal.

\subsection{Konsep Pengondisian Udara}

Pengondisian udara dapat dilakukan pada penelitian ini adalah mesin refrigerasi siklus kompresi uap. Mesin ini memiliki empat komponen utama yaitu kompresor, kondensor, katup ekspansi, dan evaporator. Skema sederhana dari sistem refrigerasi siklus kompresi uap ditunjukan pada Gambar 1.

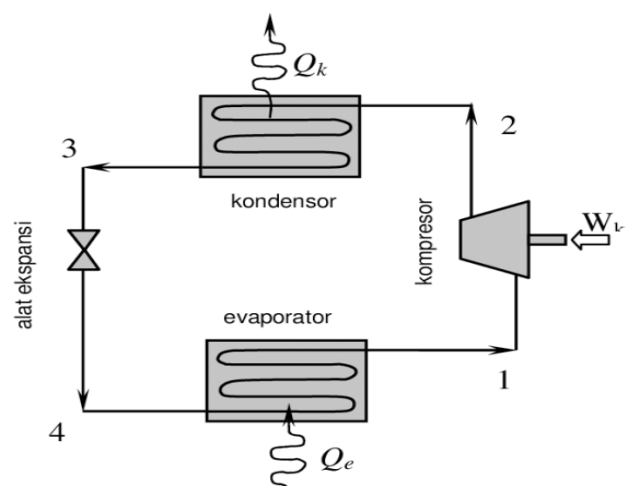

Gambar 1. Siklus kompresi uap (Azridjal Aziz, 2009)

\subsection{Beban Pendinginan}

Langkah yang paling awal dalam merancang suatu sistem tata udara adalah melakukan perhitungan beban pendinginan. Beban pendinginan adalah sejumlah energi panas yang harus dipindahkan oleh mesin pengondisi udara dari suatu ruangan untuk mencapai kondisi udara ruangan yang diinginkan baik temperatur dan kelembaban. Sumber energi panas yang ada pada suatu ruangan dapat dibedakan menjadi dua, yaitu beban yang berasal dari luar ruangan, yaitu beban eksternal, dan beban yang berasal dari dalam ruangan tersebut, yang disebut juga beban internal. Sedangkan berdasarkan jenisnya beban pendinginan dapat dibedakan menjadi dua macam, yaitu beban sensibel dan beban laten.

Metoda perhitungan beban pendinginan pada penelitian ini menggunakan metoda CLTD (Cooling Load Temperature Difference) yang merupakan salah satu metoda perhitungan beban pendinginan yang mengacu pada ASHRAE (American Society of Heating Refrigerating and Air-Conditioning Engineers).

1. Beban Eksternal

Beban pendinginan yang berasal dari luar ruangan adalah sebagai berikut:

- Beban pendinginan akibat radiasi matahari

- Beban pendinginan akibat konduksi dari selubung bangunan

- Beban pendinginan akibat pertukaran udara

2. Beban Internal

Beban pendinginan dari dalam ruangan adalah sebagai berikut:

- Beban pendinginan akibat lampu
- Beban pendinginan akibat penghuni

- Beban pendinginan akibat peralatan listrik

\subsection{Jenis Sistem Tata Udara}

Sistem tata udara diklasifikasikan menjadi dua jenis sistem utama, yaitu sistem ekspansi langsung (direct expansion) dan sistem sentral.

1. Sistem ekspansi langsung (Direct Expansion)

Sistem tata udara ekspansi langsung adalah sistem yang menggunakan siklus ekspansi atau kompresi uap refrigeran untuk mendinginkan suatu ruangan. Pada sistem ekspansi langsung, udara di dalam ruangan akan mengalami proses pendinginan secara langsung pada koil evaporator. Pada penelitian ini sistem tata udara terpisah yang dipilih sebagai alternatif adalah sistem tata udara terpisah dengan debit udara berubah, atau dikenal dengan sistem tata udara menggunakan mesin Variable Refrigerant Flow (VRF).

\section{Sistem tata udara sentral}

Sistem sentral yang digunakan pada penelitian ini adalah sistem chiller dengan debit konstan dan berubah. Chiller sebagai mesin refrigrasi menghasilkan air sejuk yang akan didistribusikan menuju unit pengolah udara dengan menggunakan pompa. Sistem pendingin sentral terdiri dari AHU/FCU, chiller, menara pendingin, pompa, perpipaan sebagai central plant, dan instalasi ducting untuk saluran udara.

\subsection{Perhitungan Life Cycle Cost}

Perhitungan life cycle cost merupakan tahap terakhir yang harus dilakukan setelah seluruh tarif dasar diketahui. Biaya perencanaan, investasi, operasional, perawatan dan pemeliharaan dari ketiga alternatif sistem dijumlahkan untuk seluruh siklus hidupnya selama tahun yang ditentukan. Dalam melakukan perhitungan analisis life cycle cost, seluruh biaya tersebut harus disetarakan menjadi nilai yang setara atau ekivalen dengan kondisi saat ini, baik itu biaya investasi maupun biaya operasional tahunan selama jangka waktu yang ditentukan. Nilai ekivalen tersebut direpresentasikan sebagai nilai present value (PV). Nilai PV didefinisikan sebagai nilai uang saat ini untuk sejumlah uang di masa depan. Adanya penyetaraan nilai mata uang ini disebabkan oleh terjadinya penurunan nilai mata uang akibat inflasi seiring dengan berjalannya waktu di masa depan.

Perhitungan nilai life cycle cost dilakukan dengan menjumlahkan seluruh nilai present value dari biaya perencanaan, investasi, operasional, dan perawatan. Dari keseluruhan biaya tersebut, hanya biaya investasi yang memiliki nilai yang sama dengan nilai present value-nya sebab biaya tersebut hanya dikeluarkan satu kali pada awal pembelian aset atau produk sehingga biaya tersebut tidak mengalami inflasi tiap tahunnya. Inflasi yang terjadi tiap tahun untuk biaya operasional juga ditetapkan konstan setiap tahunnya. Terdapat beberapa asumsi yang digunakan 
dalam melakukan perhitungan pada analisis life cycle cost, yaitu :

- Analisis LCC hanya dibatasi pada biaya investasi, biaya perencanan, operasional, dan biaya perawatan.

- Kenaikan biaya listrik dan air yakni sebesar 5\% tiap tahunnya.

- Kenaikan biaya perawatan yakni sebesar $2 \%$ tiap tahunnya.

- $\quad$ Suku bunga konstan sebesar 7,5\%.

- Analisis dilakukan untuk waktu siklus selama 20 tahun.

- Kurs rupiah konstan sebesar Rp 15.000,00/USD

Nilai present value biaya operasional dapat ditentukan melalui persamaan (1.1) hingga (1.2).

$$
\mathrm{PV}=\mathrm{A}_{0} \mathrm{x} \mathrm{UPV}
$$

$$
\begin{aligned}
\mathrm{UPV} & =\sum_{\mathrm{t}=1}^{\mathrm{n}}\left(\frac{1+\mathrm{e}}{1+\mathrm{d}}\right)^{\mathrm{t}} \\
& =\frac{(1+\mathrm{e})}{(1+\mathrm{d})}\left[1-\left(\frac{1+\mathrm{e}}{1+\mathrm{d}}\right)^{\mathrm{n}}\right] \\
\mathrm{PV}= & \mathrm{A}_{0} \frac{(1+\mathrm{e})}{(\mathrm{d}-\mathrm{e})}\left[1-\left(\frac{1+\mathrm{e}}{1+\mathrm{d}}\right)^{\mathrm{n}}\right]
\end{aligned}
$$

Keterangan :

$\begin{array}{ll}\mathrm{PV} & \text { : Present Value } \\ \mathrm{UPV} & \text { : Unit Present Value Factor } \\ \mathrm{A}_{0} & \text { : Biaya operasional tahunan } \\ \mathrm{e} & \text { : Kenaikan biaya operasional per tahun } \\ \mathrm{d} & \text { : Nilai suku bunga } \\ \mathrm{N} & \text { : Jangka waktu (tahun) }\end{array}$

\section{METODOLOGI}

\subsection{Pendekatan Penelitian}

Pendekatan penelitian adalah metode yang digunakan untuk mendekatkan permasalahan yang diteliti sehingga dapat menjelaskan dan membahas permasalahan secara tepat. Penelitian ini menggunakan metode penelitian jenis diskriptif dengan membandingkan beberapa sistem tata udara yang biasa digunakan pada bangunan hotel dilihat dari aspek energi dan biaya untuk mendapatkan sistem tata udara yang optimal.

\subsection{Metode Penelitian}

Metode penyelesaian masalah pada penelitian ini secara urut adalah sebagai berikut:

1. Studi literatur

Studi literatur dilakukan dari berbagai jurnal, handbook, standar dan peraturan yang berhubungan dengan bangunan gedung dan sistem tata udara.

2. Menentukan kondisi termal dalam bangunan

Kondisi termal yang harus ditentukan meliputi temperatur udara bola kering, kelembaban relatif, kecepatan distribusi udara, dan tingkat kebisingan yang memenuhi untuk bangunan hotel.

\section{Pengumpulan data}

Data-data yang digunakan berdasarkan data bangunan yang direncanakan oleh arsitek, meliputi data luas ruangan, arah bangunan, tinggi ruangan, dan data selubung bangunan. Untuk melengkapi data yang akan diolah harus diketahui jumlah orang, jumlah lampu, dan jumlah peralatan listrik berdasarkan fungsi masing-masing ruangan. Data tersebut dapat diambil dari standar-standar yang berlaku seperti Permen PUPR, SNI, dan ASHRAE.

\section{Estimasi beban pendinginan}

Perhitungan beban pendinginan dibantu dengan perangkat lunak Trace 700 untuk mendapatkan hasil estimasi beban pendinginan pada bangunan hotel. Hasil estimasi beban pendinginan ini akan dianalisa psikometrik dan dibandingkan dengan standar umum yang berlaku. Apabila hasilnya sudah optimal maka proses dilanjutkan, sedangkan kalau hasilnya diluar jauh dari standar akan dilakukan pengecekan lagi terhadap masukan pada perangkat lunak yang digunakan.

\section{Perencanaan distribusi udara}

Perencanaan sistem distribusi udara dapat dilakukan dengan menggunakan bantuan perangkat lunak Duct Designer. Melalui bantuan perangkat lunak tersebut, nilai pressure drop dari instalasi cerobong udara dapat diperoleh. Nilai pressure drop ini akan digunakan untuk menentukan spesifikasi teknis dari mesin AHU/FCU. Metode yang digunakan untuk menentukan dimensi cerobong udara dan faktor gesek adalah equal friction.

\section{Perencanaan sistem perpipaan}

Menghitung head loss pada sistem perpipaan, baik pemipaan air sejuk maupun air dingin berdasarkan perancangan instalasi masing-masing sistem. Selain perhitungan head loss pemipaan juga perhitungan debit air sejuk dan air dingin. Kedua data tersebut akan digunakan untuk menentukan spesikasi teknis dari pompa air sejuk dan pompa air dingin menggunakan bantuan perangkat lunak online Grundfos. Untuk perhitungan dimensi pipa sistem udara terpisah (split) menggunakan bantuan perangkat lunak Daikin.

\section{Pemilihan menara pendingin}

Dalam menentukan kapasitas menara pendingin, terdapat beberapa parameter yang harus diperhatikan. Salah satunya adalah temperatur masuk dan keluar menara pendingin. Selain hal tersebut adalah temperatur basah udara luar dan debit air dingin menara pendingin. Berdasarkan data tersebut seleksi menara pendingin dapat dilakukan dengan menggunakan perangkat lunak menara pendingin.

8. Analisis Energi

Analisis energi dilakukan dengan melakukan perhitungan konsumsi energi listrik untuk masing-masing sistem tata udara dari beberapa alternatif yang dipilih selama 1 tahun. Sistem yang akan dibandingkan dan dianalis yaitu sistem tata udara sentral yang terdiri dari mesin chiller dengan debit konstan, sistem tata udara sentral dengan mesin chiller dengan debit berubah, dan sistem tata udara terpisah (split) mesin jenis VRF(Variable Refrigerant Flow). Sistem tata udara yang mempunyai konsumsi energi yang baik, dimana nilai IKE nya dibawah standar dari 
Pergub DKI Jakarta No.38 Tahun 2012.

9. Analisis Biaya

Analisis biaya dilakukan dengan melakukan perbandingan dari aspek konsumsi energi listrik dan biaya dari berbagai alternatif sistem udara yang akan digunakan. Metoda untuk melakukan analisa biaya menggunakan metoda analisis LCC (Life-Cycle Cost). Metoda analisis life cycle cost didasari oleh perhitungan seluruh biaya yang terjadi pada suatu produk atau

sistem selama satu siklus hidup. Siklus hidup dari produk atau sistem tersebut dimulai dari tahap perancangan, investasi, pengoperasian, perawatan, dan pembuangan. Namun dalam penelitian ini, hanya dilakukan analisis life cycle cost terbatas hanya pada tahap perencanaan, investasi, pengoperasian, dan perawatan. Selain itu, metoda analisis life cycle cost disesuaikan berdasarkan umur hidup dari suatu produk. Pada penelitian ini dilakukan analisis life cycle cost dengan jangka waktu 20 tahun.

Diagram alir metodologi penelitian tentang studi komparasi beberapa sistem tata udara yang digunakan pada bangunan gedung dapat dilihat pada Gambar 2.

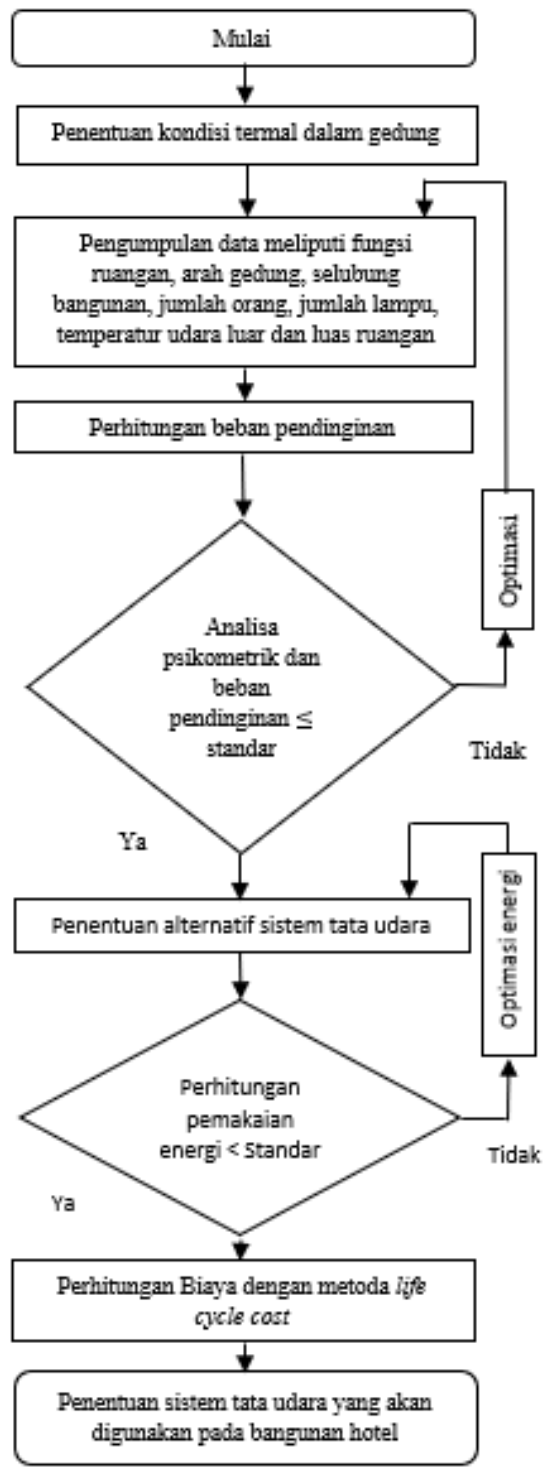

Gambar 2. Diagram alir metodologi penelitian

\subsection{Pengumpulan Data}

1. Lokasi bangunan hotel

Bangunan hotel yang akan dianalisis pada studi kali ini terletak di Jakarta yang memiliki letak geografis pada 6019'00" Lintang Selatan dan 106 43'00" Bujur Timur. Berdasarkan SNI 03-6390-2011 tentang Konservasi energi sistem tata udara bangunan gedung (BSNI,2011:3), kondisi udara luar perancangan pada kawasan tersebut memiliki temperatur bola kering rata-rata maksimum sebesar $33^{\circ} \mathrm{C}$ dan bola basah rata-rata maksimum sebesar $27^{\circ} \mathrm{C}$.

\section{Data dan denah bangunan}

Hotel ini terdiri dari 16 lapis dengan 4 basemen dengan luas daerah total yang dikondisikan sebesar 23.246 $\mathrm{m}^{2}$ dan luas bangunan sebesar $32.411 \mathrm{~m}^{2}$.

3. Nilai koefisien perpindahan panas selubung bangunan

Nilai koefisien perpindahan panas keseluruhan bergantung pada beberapa parameter, seperti ketebalan bahan bangunan dan karakteristik material bangunan itu sendiri. Semua ruangan pada hotel diasumsikan memiliki nilai koefisien perpindahan panas keseluruhan atau nilai $\mathrm{U}$ yang sama untuk bahan dan komposisi selubung bangunan yang sama. Beberapa nilai U yang digunakan pada bangunan ini adalah sebagai berikut:

$$
\begin{array}{ll}
\text { - } & \text { Nilai U dinding } \\
\text { - } & \text { Nilai U partisi } \\
\text { - } & \text { Nilai U atap } \\
\text { - } & \text { Nilai U lantai } \\
\text { - } & \text { Nilai U kaca } \\
\hline & \text { NC kaca }
\end{array}
$$

$$
\begin{aligned}
& : 1,673 \mathrm{~W} / \mathrm{m}^{2} \mathrm{~K} \\
& : 2,497 \mathrm{~W} / \mathrm{m}^{2} \mathrm{~K} \\
& : 0,497 \mathrm{~W} / \mathrm{m}^{2} \mathrm{~K} \\
& : 1,111 \mathrm{~W} / \mathrm{m}^{2} \mathrm{~K} \\
& : 1,873 \mathrm{~W} / \mathrm{m}^{2} \mathrm{~K} \\
& : 0,38
\end{aligned}
$$

\section{Asumsi beban pendinginan}

Beban panas yang berasal dari berbagai macam sumber, baik itu eksternal maupun internal, nilai-nilainya telah ditetapkan sesuai dengan standar yang dikeluarkan oleh Badan Standarisasi Nasional. Standar yang digunakan dalam menentukan kebutuhan ventilasi tiap ruangan dan beban sensible serta laten dari penghuni adalah 03-63722001 mengenai "Tata Cara Perancangan Sistem Ventilasi dan Pengondisian Udara". Sedangkan, untuk mengetahui kebutuhan kepadatan penghuni mengacu pada standar internasional ASHRAE Standard 62.1-2007 [18]. Daya yang dihasilkan oleh lampu dan beban peralatan listrik per satuan luas setiap bangunan mengacu pada data rancangan elektrikal masing-masing ruangan.

\section{Schedule setiap ruangan}

Schedule dibagi menjadi tiga jenis, yaitu penggunaan lampu, alat elektronik, dan kepadatan penghuni. Pada bangunan hotel ini, schedule akan mempengaruhi kurva beban pendinginan di setiap waktunya.

\section{Desain temperatur dan kelembaban ruangan}

Berdasarkan SNI 03-6572-2001 "Tata Cara Perancangan Sistem Ventilasi dan Pengkondisian Udara pada Bangunan Gedung" halaman 11 dan halaman 18, dipilih kondisi perancangan temperatur udara dalam ruangan $25^{\circ} \mathrm{C} 1{ }^{\circ} \mathrm{C}$ dan kelembaban udara relatif 55\%10\%. 


\section{Beban lampu}

Berdasarkan SNI 03-6197-2011, Konservasi energi sistem pencahayaan (BSN, 2011:6), estimasi beban lampu ditentukan berdasarkan fungsi ruangannya. Sedangkan estimasi beban peralatan listrik berdasarkan titik peralatan listrik pada gambar arsitektur.

\subsection{Beban Pendinginan}

Estimasi beban pendinginan pada penelitian ini dilakukan dengan menggunakan perangkat lunak Trace 700. Beban pendinginan total dari satu bangunan hotel dapat dilihat melalui kurva karakteristik beban. Kurva karakteristik tersebut mengambarkan hubungan antara besarnya beban pendinginan total suatu bangunan hotel dan jumlah seluruh jam operasi dalam satu hari. Kurva karakteristik beban pendinginan pada bangunan hotel dibagi ke dalam dua waktu yaitu pada saat hari kerja (weekdays) dan akhir pekan atau hari libur (weekend). Asumsi jumlah penghuni hotel pada waktu weekday adalah $50 \%$ dan pada waktu weekend $100 \%$. Hal tersebut dilakukan guna mengetahui besarnya beban pendinginan rata-rata yang harus diatasi oleh sistem tata udara sebagai bagian dari analisis energi. Dalam perhitungan energi pada penelitian ini diasumsikan beban pendinginan weekend dihitung 2 hari dalam satu minggu dan beban pendinginan weekday dihitung 5 hari dalam satu minggu. Profil beban pendinginan dari kedua waktu tersebut dapat dilihat pada Gambar 3 dan 4.

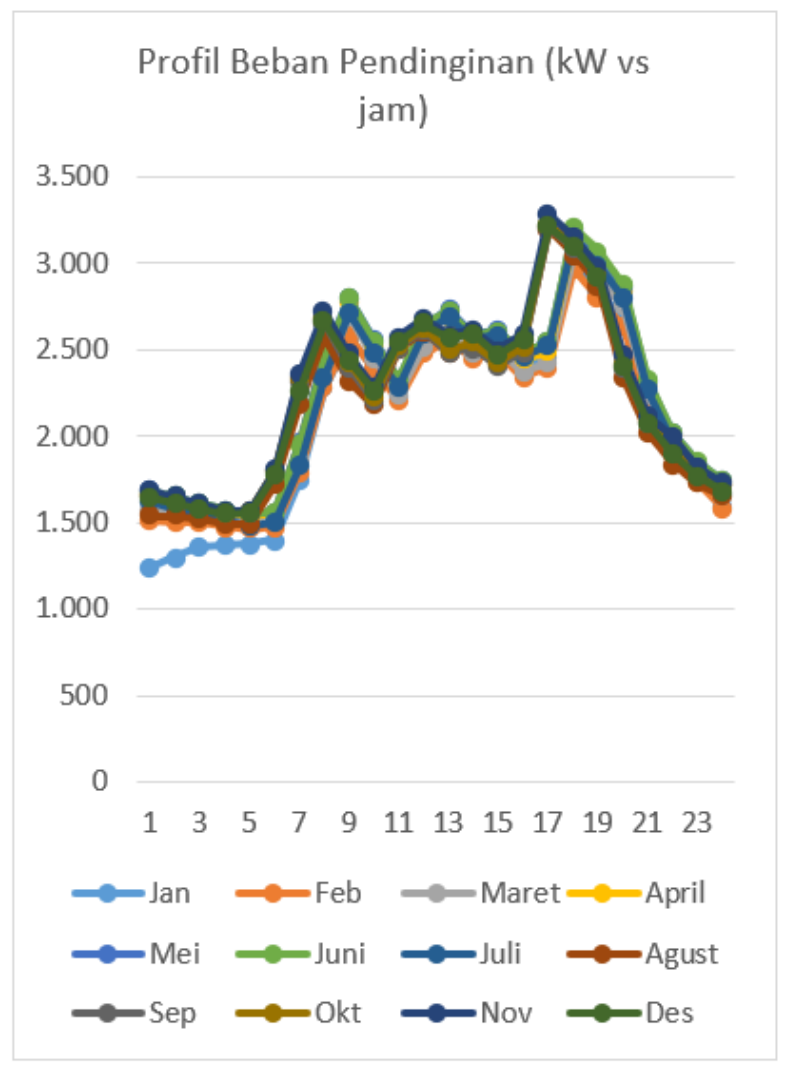

Gambar 3. Beban pendinginan weekend

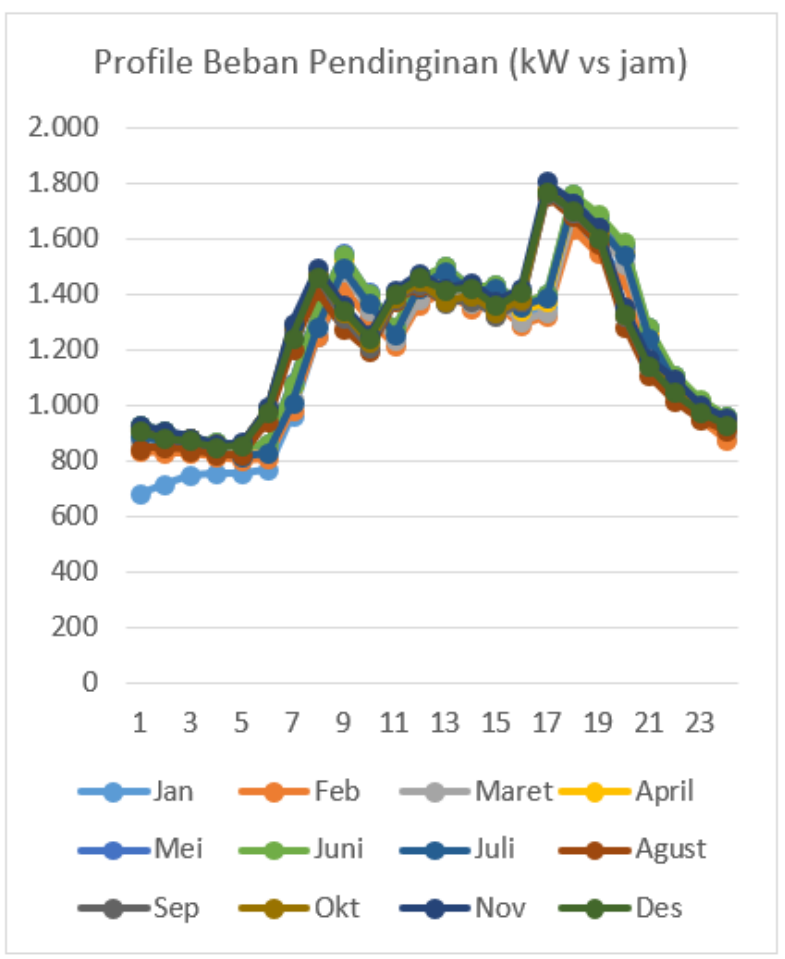

Gambar 4. Beban pendinginan weekday

Dari Gambar 3 dan 4, diketahui bahwa beban pendinginan maksimum terjadi di akhir minggu pada bulan November dan beban terendah terjadi di hari kerja pada bulan Januari. Beban pendinginan maksimum yang terjadi sebesar $3.279 \mathrm{~kW}$ selama 1 jam, dari mulai pukul 17.00.

Dalam menentukan besarnya energi listrik yang dikonsumsi setiap tahunnya, dibutuhkan beban pendinginan selama 12 bulan untuk kedua waktu tersebut setiap jamnya, baik weekend maupun weekdays sehingga dapat diketahui seberapa besar perbedaa konsumsi energi listrik antara hari kerja dan akhir minggu. 
Tabel 1. Profil beban pendinginan hotel pada weekend

\begin{tabular}{|c|c|c|c|c|c|c|c|c|c|c|c|c|}
\hline \multicolumn{13}{|c|}{ Profil Beban Pendinginan Weekend } \\
\hline Jam & Jan & Feb & Maret & April & Mei & Juni & Juli & Agust & Sep & Okt & Nov & Des \\
\hline 01.00 & 1.234 & 1.514 & 1.572 & 1.661 & 1.687 & 1.683 & 1.621 & 1.537 & 1.659 & 1.674 & 1.688 & 1.645 \\
\hline 02:00 & 1.301 & 1.505 & 1.576 & 1.613 & 1.647 & 1.646 & 1.577 & 1.539 & 1.628 & 1.637 & 1.647 & 1.608 \\
\hline 03:00 & 1.356 & 1.502 & 1.564 & 1.592 & 1.608 & 1.608 & 1.546 & 1.525 & 1.599 & 1.604 & 1.611 & 1.580 \\
\hline 04:00 & 1.375 & 1.477 & 1.545 & 1.564 & 1.574 & 1.573 & 1.510 & 1.491 & 1.559 & 1.564 & 1.569 & 1.549 \\
\hline 05:00 & 1.376 & 1.460 & 1.524 & 1.539 & 1.547 & 1.547 & 1.482 & 1.494 & 1.564 & 1.568 & 1.572 & 1.556 \\
\hline 06:00 & 1.399 & 1.474 & 1.540 & 1.557 & 1.564 & 1.563 & 1.502 & 1.717 & 1.793 & 1.797 & 1.803 & 1.777 \\
\hline 07:00 & 1.743 & 1.783 & 1.862 & 1.959 & 1.965 & 1.950 & 1.824 & 2.182 & 2.316 & 2.340 & 2.357 & 2.260 \\
\hline 08:00 & 2.275 & 2.274 & 2.344 & 2.455 & 2.465 & 2.451 & 2.333 & 2.566 & 2.653 & 2.681 & 2.717 & 2.661 \\
\hline 09:00 & 2.563 & 2.579 & 2.695 & 2.780 & 2.804 & 2.801 & 2.711 & 2.318 & 2.390 & 2.424 & 2.473 & 2.435 \\
\hline 10:00 & 2.397 & 2.384 & 2.441 & 2.524 & 2.552 & 2.546 & 2.477 & 2.177 & 2.201 & 2.228 & 2.280 & 2.263 \\
\hline 11:00 & 2.225 & 2.203 & 2.236 & 2.300 & 2.326 & 2.328 & 2.277 & 2.505 & 2.509 & 2.526 & 2.575 & 2.547 \\
\hline $12: 00$ & 2.496 & 2.473 & 2.516 & 2.599 & 2.634 & 2.640 & 2.592 & 2.603 & 2.608 & 2.626 & 2.682 & 2.650 \\
\hline $13: 00$ & 2.597 & 2.556 & 2.608 & 2.694 & 2.729 & 2.724 & 2.691 & 2.488 & 2.484 & 2.505 & 2.585 & 2.569 \\
\hline $14: 00$ & 2.513 & 2.446 & 2.485 & 2.556 & 2.585 & 2.579 & 2.561 & 2.511 & 2.508 & 2.539 & 2.615 & 2.589 \\
\hline $15: 00$ & 2.538 & 2.474 & 2.504 & 2.578 & 2.611 & 2.607 & 2.586 & 2.415 & 2.402 & 2.427 & 2.497 & 2.469 \\
\hline 16:00 & 2.399 & 2.341 & 2.371 & 2.441 & 2.477 & 2.475 & 2.458 & 2.501 & 2.489 & 2.517 & 2.588 & 2.557 \\
\hline $17: 00$ & 2.456 & 2.400 & 2.424 & 2.491 & 2.541 & 2.543 & 2.522 & 3.191 & 3.203 & 3.224 & 3.279 & 3.211 \\
\hline $18: 00$ & 3.013 & 2.968 & 3.052 & 3.142 & 3.195 & 3.202 & 3.142 & 3.049 & 3.086 & 3.103 & 3.151 & 3.097 \\
\hline 19:00 & 2.837 & 2.804 & 2.915 & 3.008 & 3.045 & 3.069 & 2.984 & 2.872 & 2.926 & 2.941 & 2.980 & 2.918 \\
\hline 20:00 & 2.665 & 2.637 & 2.749 & 2.835 & 2.865 & 2.877 & 2.797 & 2.338 & 2.398 & 2.415 & 2.463 & 2.408 \\
\hline 21:00 & 2.218 & 2.183 & 2.239 & 2.294 & 2.320 & 2.326 & 2.264 & 2.019 & 2.069 & 2.084 & 2.120 & 2.074 \\
\hline 22:00 & 1.911 & 1.894 & 1.948 & 1.999 & 2.014 & 2.022 & 1.966 & 1.841 & 1.937 & 1.956 & 1.991 & 1.897 \\
\hline 23:00 & 1.746 & 1.730 & 1.788 & 1.836 & 1.851 & 1.855 & 1.797 & 1.724 & 1.796 & 1.804 & 1.821 & 1.771 \\
\hline 24:00 & 1.595 & 1.585 & 1.662 & 1.723 & 1.748 & 1.748 & 1.674 & 1.651 & 1.716 & 1.721 & 1.732 & 1.683 \\
\hline
\end{tabular}

Tabel 2. Profil beban pembebanan hotel pada weekday

\begin{tabular}{|c|c|c|c|c|c|c|c|c|c|c|c|c|}
\hline \multicolumn{13}{|c|}{ Profil Beban Pendinginan Weekday } \\
\hline Jam & Jan & Feb & Maret & April & Mei & Juni & Juli & Agust & Sep & Okt & Nov & Des \\
\hline 01.00 & 679 & 833 & 865 & 914 & 928 & 926 & 892 & 845 & 912 & 921 & 929 & 904 \\
\hline 02:00 & 716 & 827 & 867 & 887 & 906 & 905 & 867 & 846 & 895 & 900 & 906 & 884 \\
\hline 03:00 & 746 & 826 & 860 & 876 & 885 & 884 & 850 & 839 & 879 & 882 & 886 & 869 \\
\hline 04:00 & 756 & 812 & 850 & 860 & 866 & 865 & 830 & 820 & 858 & 860 & 863 & 852 \\
\hline 05:00 & 757 & 803 & 838 & 847 & 851 & 851 & 815 & 822 & 860 & 862 & 865 & 856 \\
\hline 06:00 & 770 & 811 & 847 & 856 & 860 & 860 & 826 & 944 & 986 & 988 & 992 & 977 \\
\hline 07:00 & 959 & 981 & 1.024 & 1.077 & 1.081 & 1.072 & 1.003 & 1.200 & 1.274 & 1.287 & 1.297 & 1.243 \\
\hline 08:00 & 1.251 & 1.251 & 1.289 & 1.351 & 1.356 & 1.348 & 1.283 & 1.411 & 1.459 & 1.475 & 1.494 & 1.463 \\
\hline 09:00 & 1.410 & 1.418 & 1.482 & 1.529 & 1.542 & 1.541 & 1.491 & 1.275 & 1.315 & 1.333 & 1.360 & 1.339 \\
\hline 10:00 & 1.318 & 1.311 & 1.343 & 1.388 & 1.404 & 1.400 & 1.362 & 1.197 & 1.211 & 1.225 & 1.254 & 1.245 \\
\hline 11:00 & 1.224 & 1.212 & 1.230 & 1.265 & 1.279 & 1.280 & 1.252 & 1.377 & 1.380 & 1.389 & 1.416 & 1.401 \\
\hline 12:00 & 1.373 & 1.360 & 1.384 & 1.429 & 1.449 & 1.452 & 1.426 & 1.431 & 1.434 & 1.444 & 1.475 & 1.458 \\
\hline 13:00 & 1.428 & 1.406 & 1.434 & 1.481 & 1.501 & 1.498 & 1.480 & 1.368 & 1.366 & 1.378 & 1.422 & 1.413 \\
\hline 14:00 & 1.382 & 1.345 & 1.367 & 1.406 & 1.422 & 1.418 & 1.408 & 1.381 & 1.380 & 1.397 & 1.438 & 1.424 \\
\hline 15:00 & 1.396 & 1.361 & 1.377 & 1.418 & 1.436 & 1.434 & 1.422 & 1.328 & 1.321 & 1.335 & 1.373 & 1.358 \\
\hline 16:00 & 1.319 & 1.288 & 1.304 & 1.342 & 1.362 & 1.361 & 1.352 & 1.375 & 1.369 & 1.384 & 1.423 & 1.407 \\
\hline $17: 00$ & 1.351 & 1.320 & 1.333 & 1.370 & 1.398 & 1.399 & 1.387 & 1.755 & 1.762 & 1.773 & 1.803 & 1.766 \\
\hline 18:00 & 1.657 & 1.633 & 1.679 & 1.728 & 1.757 & 1.761 & 1.728 & 1.677 & 1.697 & 1.707 & 1.733 & 1.703 \\
\hline 19:00 & 1.560 & 1.542 & 1.603 & 1.654 & 1.675 & 1.688 & 1.641 & 1.580 & 1.609 & 1.617 & 1.639 & 1.605 \\
\hline 20:00 & 1.466 & 1.450 & 1.512 & 1.559 & 1.576 & 1.583 & 1.538 & 1.286 & 1.319 & 1.328 & 1.355 & 1.325 \\
\hline 21:00 & 1.220 & 1.201 & 1.232 & 1.262 & 1.276 & 1.279 & 1.245 & 1.110 & 1.138 & 1.146 & 1.166 & 1.141 \\
\hline 22:00 & 1.051 & 1.042 & 1.071 & 1.099 & 1.108 & 1.112 & 1.081 & 1.013 & 1.065 & 1.076 & 1.095 & 1.043 \\
\hline
\end{tabular}




\begin{tabular}{ccccccccccccc}
$23: 00$ & 960 & 951 & 983 & 1.010 & 1.018 & 1.020 & 988 & 948 & 988 & 992 & 1.001 & 974 \\
$24: 00$ & 877 & 872 & 914 & 948 & 961 & 962 & 921 & 908 & 944 & 946 & 953 & 926 \\
\hline
\end{tabular}

\section{HASIL DAN PEMBAHASAN}

\subsection{Pemilihan Sistem Tata Udara}

Hasil estimasi beban pendinginan bangunan hotel menunjukkan bahwa terjadi fluktuasi beban pendinginan setiap jamnya yang dipresentasikan melalui pendinginan maksimum sebesar $3.281 \mathrm{~kW}$ dan beban minimum sebesar $303 \mathrm{~kW}$. Berdasarkan hasil estimasi beban pendinginan akan dipilih beberapa alternatif sistem tata udara yang biasa digunakan pada bangunan hotel yaitu:

1. Sistem tata udara sentral yang terdiri dari mesin chiller dengan debit konstan, disebut sebagai Alternatif 1.

2. Sistem tata udara sentral dengan mesin chiller dengan debit berubah, disebut sebagai Alternatif 2 .

3. Sistem tata udara terpisah (split) mesin jenis $V R F$ (Variable Refrigerant Flow), disebut sebagai Alternatif 3.

\subsection{Analisis Energi Sistem Tata Udara}

Untuk menentukan pilihan terbaik dari ketiga alternatif sistem tata udara tersebut akan dilakukan analisis konsumsi energi terhadap masing-masing sistem tersebut. Sistem tata udara dikatakan efisien dari energi apabila konsumsi energi listriknya rendah. Efisiensi bangunan dalam mengkonsumsi energi listrik dapat ditunjukkan oleh suatu nilai yang disebut sebagai nilai IKE (Intensitas Konsumsi Energi) bangunan, khususnya yang berkaitan dengan sistem tata udara.

1. Sistem chiller dengan debit konstan

Tabel 3. Konsumsi energi chiller debit konstan

\begin{tabular}{lr}
\hline Uraian & kWh/tahun \\
\hline Chiller & 2.348 .179 \\
Pompa Chiller & 266.266 \\
Menara Pendingin & 257.693 \\
Pompa Menara Pendingin & 214.593 \\
AHU & 477.899 \\
\hline Total & 3.564 .630 \\
\hline
\end{tabular}

2. Sistem chiller dengan debit berubah

Tabel 4. Konsumsi energi chiller debit berubah

\begin{tabular}{lr}
\hline Uraian & kWh/tahun \\
\hline Chiller & 1.952 .240 \\
Pompa Chiller & 118.257 \\
Menara Pendingin & 113.097 \\
Pompa Menara Pendingin & 88.143 \\
AHU & 477.899 \\
\hline Total & 2.749 .636 \\
\hline
\end{tabular}

3. Sistem terpisah (Split) VRF

Tabel 3.3 Konsumsi energi VRF

\begin{tabular}{lr}
\hline Uraian & $\mathrm{kWh} /$ tahun \\
\hline VRF & 3.851 .822 \\
\hline Total & 3.851 .822 \\
\hline
\end{tabular}

Berdasarkan hasil perhitungan konsumsi energi tersebut di atas dapat dilihat perbandingannya yang ditunjukkan pada Tabel 5.

Tabel 5. Konsumsi energi sistem tata udara

\begin{tabular}{lc}
\hline Uraian & $\mathrm{kWh} /$ tahun \\
\hline Alternatif 1 & 3.564 .630 \\
Alternatif 2 & 2.749 .636 \\
Alternatif 3 & 3.851 .822 \\
\hline
\end{tabular}

Sistem tata udara sentral menggunakan mesin chiller dengan debit berubah merupakan sistem yang paling kecil mempunyai konsumsi energi listrik pada bangunan hotel ini sebesar 2.749.636 kWh/tahun. Dan sistem tata udara terpisah dengan menggunakan VRF mempunyai konsumsi energi listrik paling besar setiap tahunnya yaitu 3.851 .822 kWh.

Tabel 6. Nilai IKE sistem tata udara

\begin{tabular}{lc}
\hline Uraian & $\mathrm{kWh} / \mathrm{m}^{2}$.tahun \\
\hline Alternatif 1 & 153 \\
Alternatif 2 & 118 \\
Alternatif 3 & 166 \\
\hline
\end{tabular}

Dari Tabel 6 tersebut, nilai IKE tata udara sistem Alternatif 1, Alternatif 2, dan Alternatif 3 masih berada pada batas efisien dengan ketentuan nilai yang lebih rendah dibandingkan nilai IKE standar sebesar 227,5 kWh/ $\mathrm{m}^{2}$.tahun. Selain itu sistem Alternatif 2 yaitu sistem tata udara sentral menggunakan mesin chiller dengan debit berubah mempunyai efisiensi paling baik dibanding alternatif sistem tata udara yang lain dengan ditunjukkan nilai IKE nya sebesar $118 \mathrm{kWh} / \mathrm{m}^{2}$.tahun. Sedangkan Alternatif 3 yaitu sistem tata udara terpisah VRF mempunyai nilai IKE yang paling besar yaitu $166 \mathrm{kWh} / \mathrm{m}^{2}$.tahun.

\subsection{Kebutuhan Air pada Menara Pendingin}

Sistem tata udara sentral Alternatif 1 dan Alternatif 2 menggunakan air untuk mendinginkan refrigeran pada koil kondensor, sedangkan sistem tata udara Alternatif 3 menggunakan udara untuk mendinginkan refrigeran pada koil kondensornya. Air dingin yang digunakan untuk mendinginkan refrigeran tersebut dilakukan oleh menara pendingin. Pada proses pendinginan air tersebut menggunakan proses perpindahan panas antara udara di sekitar dengan air yang disirkulasi dari mesin chiller menuju menara pendingin. Proses tersebut menyebabkan 
terbuangnya air karena proses evaporasi, drift loss, dan proses blow-down. Jumlah air yang hilang karena proses tersebut ditunjukkan pada Tabel 7.

Tabel 7. Konsumsi air menara pendingin

\begin{tabular}{lc}
\hline Uraian & $\begin{array}{c}\text { Konsumsi Air } \\
\left(\mathrm{m}^{3} / \text { tahun }\right)\end{array}$ \\
\hline Alternatif 1 & 19.650 \\
Alternatif 2 & 19.650 \\
Alternatif 3 & 0 \\
\hline
\end{tabular}

\subsection{Analisis LCC (Life Cycle Cost)}

Setelah diketahui sistem yang paling efisien terhadap aspek energi, dilakukan perhitungan biaya sebagai analisis dari aspek biaya. Analisis biaya yang digunakan pada perancangan ini menggunakan metoda analisis life cycle cost. Metoda yang terjadi life cycle cost didasari oleh perhitungan seluruh biaya pada suatu produk atau sistem selama satu siklus hidup. Siklus hidup dari produk atau sistem dimulai dari perancangan, investasi, pengoperasian, perawatan, dan pembuangan. Namun dalam perancangan ini hanya dilakukan sebagian analisis life cycle cost terbatas pada biaya perancangan, investasi, pengoperasian, dan perawatan. Selain itu metoda analisis life cycle cost ini disesuaikan berdasarkan umur hidup suatu produk. Pada studi perancangan ini, dilakukan analisis life cycle cost dengan jangka waktu 20 tahun. Hal tersebut dilakukan untuk melihat seberapa besar perbedaan biaya yang terjadi untuk ketiga alternatif sistem tata udara tersebut.

\section{a) Biaya Perancangan}

Perhitungan biaya perancangan berdasarkan data yang didapat dari INKINDO (Ikatan Nasional Konsultan Indonesia) provinsi DKI Jakarta yang didasarkan pada biaya langsung personil per bulan tahun 2020 dalam bukunya yang berjudul 'PEDOMAN STANDAR MINIMAL TAHUN 2020". Harga estimasi biaya yang didapatkan untuk ketiga alternatif sistem tata udara ini adalah sama sebesar Rp. 819.500.000,00.

\section{b) Biaya Investasi}

Biaya investasi merupakan biaya yang dikeluarkan oleh pengembang pertama kali pada awal pembelian produk yang sesuai dengan sistem tata udara hasil perancangan. Biaya investasi pada sistem tata udara ini terdiri dari beberapa komponen produk seperti dijabarkan pada Tabel 3.7 .

Tabel 3.7 Perbandingan biaya investasi masing-masing sistem tata udara

\begin{tabular}{lc}
\hline Uraian & $\begin{array}{c}\text { Biaya } \\
(\mathrm{Rp} .)\end{array}$ \\
\hline Alternatif 1 & $29.368 .290 .000,00$ \\
Alternatif 2 & $31.584 .635 .750,00$ \\
Alternatif 3 & $37.311 .696 .000,00$ \\
\hline
\end{tabular}

\section{c) Biaya Operasional Listrik dan Air}

Biaya opersional merupakan biaya yang harus dikeluarkan untuk mengoperasikan atau menjalankan suatu sistem. Biaya operasional umumnya memiliki sifat habis pakai dalam kurun waktu yang relatif singkat (kurang dari satu tahun). Biaya operasional pada sistem tata udara terdiri dari biaya operasional listrik dan biaya air pengganti yang hilang karena proses di menara pendingin. Untuk mendapatkan biaya operasional listrik, konsumsi energi listrik yang dibutuhkan dari suatu bangunan perlu diketahui terlebih dahulu. Berdasarkan referensi tarif dasar listrik yang dikeluarkan oleh PLN [23], bangunan hotel ini memiliki kebutuhan listrik di atas $200 \mathrm{kVA}$ dan termasuk golongan bisnis besar (B-3). Sedangkan untuk menghitung besarnya air yang hilang akibat proses di menara pendingin, menggunakan asumsi bahwa besarnya debit air yang hilang sebesar $1 \%$ dari debit air pada pompa kondensor [21]. Tarif air yang digunakan adalah tarif dasar yang dikeluarkan oleh PAM DKI [24]. Biaya operasional pada bangunan hotel ini dapat dilihat pada Tabel 8.

Tabel 8. Biaya operasional listrik dan air

\begin{tabular}{lc}
\hline Uraian & $\begin{array}{c}\text { Biaya } \\
\text { (Rp.) }\end{array}$ \\
\hline Alternatif 1 & $4.220 .248 .476,00$ \\
Alternatif 2 & $3.311 .742 .019,00$ \\
Alternatif 3 & $4.293 .779 .263,00$ \\
\hline
\end{tabular}

d) Biaya Perawatan

Biaya perawatan dan pemeliharaan adalah biaya yang dikeluarkan untuk memelihara produk agar suatu produk tetap berada dalam kondisi baik sehingga dapat beroperasi terus menerus secara berkelanjutan. Biaya perawatan umumnya dikeluarkan secara berkala untuk mencegah terjadinya kegagalan produk. Biaya perawatan dan pemeliharaan terdiri dari perawatan dan penggantian suku cadang komponen penyusun sistem tata udara. Biaya operasional untuk perawatan dan pemeliharaan dapat dilihat pada Tabel 9.

Tabel 9. Biaya perawatan masing-masing sistem tata udara

\begin{tabular}{lc}
\hline Uraian & $\begin{array}{c}\text { Biaya } \\
(\mathrm{Rp} .)\end{array}$ \\
\hline Alternatif 1 & $255.150 .000,00$ \\
Alternatif 2 & $255.150 .000,00$ \\
Alternatif 3 & $1.042 .000 .000,00^{*}$ \\
& $187.560 .000,00$ \\
\hline * biaya penggantian kompresor setelah umur VRF 10 tahun
\end{tabular}

\subsection{Perhitungan life cycle cost}

Perhitungan life cycle cost merupakan tahap akhir yang harus dilakukan setelah seluruh tarif dasar diketahui. Biaya perancangan, investasi, operasional, dan perawatan dari ketiga alternatif sistem dijumlahkan untuk seluruh siklus hidupnya selama 20 tahun. Dalam melakukan perhitungan pada analisis life cycle cost, seluruh biaya tersebut harus disetarakan menjadi nilai yang setara atau 
ekivalen dengan kondisi saat ini, baik itu biaya investasi maupun biaya operasional tahunan selama jangka waktu yang ditentukan. Nilai ekivalen tersebut direpresentasikam sebagai nilai present value (PV). Nilai PV didefinisikan sebagai nilai uang saat ini untuk sejumlah uang di masa depan. Adanya penyetaraan nilai mata uang ini disebabkan oleh terjadinya penurunan nilai mata uang akibat inflasi seiring dengan berjalannya waktu ke masa depan. Setelah dihitung menggunakan persamaan (1.2), didapatkan faktor UPV yang berbeda untuk biaya operasional dan biaya perawatan. Didapatkan nilai UPV untuk biaya operasional sebesar 15,77 dan untuk biaya perawatan sebesar 12,06. Kedua nilai tersebut merupakan nilai UPV yang digunakan dalam analisis life cycle cost dengan jangka waktu 20 tahun ke depan. Nilai UPV kemudian dikalikan dengan biaya operasional dan biaya perawatan untuk mendapatkan nilai present value-nya jika produk masih beroperasi dalam jangka waktu 20 tahun. Perincian biaya untuk ketiga alternatif dapat dilihat pada Tabel 10 .

Tabel 10. Life cycle cost dalam jangka waktu 20 tahun

\begin{tabular}{lc}
\hline Uraian & $\begin{array}{c}\text { Biaya } \\
\text { (Rp.) }\end{array}$ \\
\hline Alternatif 1 & $99.836 .217 .467,00$ \\
Alternatif 2 & $87.707 .416 .390,00$ \\
Alternatif 3 & $109.148 .074 .365,00$ \\
\hline
\end{tabular}

\section{KESIMPULAN}

Berdasarkan hasil perancangan dan analisis yang sudah dilakukan, dapat diperoleh beberapa kesimpulan sebagai berikut:

1. Dari beban pendinginan yang terjadi dalam 1 tahun beban puncak yang terjadi sebesar $3.279 \mathrm{~kW}$ terjadi pada bulan November jam 17.00. Beban pendinginan puncak ini dijadikan dasar dalam pemilihan kapasitas pendinginan komponen sistem tata udara.

2. Berdasarkan analisis energi dan biaya sistem tata udara Alternatif 2, yaitu sistem tata udara sentral yang menggunakan mesin chiller dengan debit berubah merupakan sistem tata udara yang dipilih sebagai alternatif solusi. Chiller yang digunakan adalah mesin chiller yang menggunakan kompresor jenis magnetic bearing yang dilengkapi dengan VSD. Jumlah mesin chiller yang digunakan adalah 3 unit dengan kapasitas pendinginan sebesar $1.100 \mathrm{~kW}$. Sedangkan untuk mengantisipasi kalau terjadi kerusakan mesin chiller disediakan 1 unit mesin chiller cadangan dengan kapasitas pendinginan $1.100 \mathrm{~kW}$.

3. Perbandingan ketiga alternatif tersebut dilakukan sebagai upaya dalam menentukan alternatif yang paling optimal dari seluruh sistem. Dari aspek energi, Alternatif 2 memiliki nilai IKE sebesar $118 \mathrm{kWh} / \mathrm{m} 2$.tahun dan dari aspek biaya, menurut analisis life cycle cost untuk jangka waktu 20 tahun, Alternatif 2 membutuhkan biaya keseluruhan sebesar Rp.87.707.416.390,00.

\section{DAFTAR PUSTAKA}

Arthur A. Bell, Jr. (2007). HVAC Equations, Data, and Rules Of Thumbs. The McGraw-Hill Companies, Inc. United States of America.

ASHRAE. (2007). Ventilation for Acceptable Indoor Air Quality. American Society of Heating, Ventilating, and Air Conditioning Engineers, Inc. United States of America: ASHRAE Standard 62.12007.

ASHRAE. (2008). ASHRAE Handbook System and Equipment. American Society of Heating, Ventilating, and Air Conditioning Engineers, Inc. United States of America.

ASHRAE. (2013). ASHRAE Handbook Fundamental. American Society of Heating, Ventilating, and Air Conditioning Engineers, Inc. United States of America.

ASHRAE. (2015). ASHRAE Handbook Application. American Society of Heating, Ventilating, and Air Conditioning Engineers, Inc. United States of America.

ASHRAE. (2017). ASHRAE Pocket Guide for Air Conditioning, Heating, Ventilation, Refrigeration 9th. American Society of Heating, Ventilating, and Air Conditioning Engineers, Inc. United States of America.

Badan Standardisasi Nasional (2011). Konservasi Energi Sistem Tata Udara Bangunan Gedung. Jakarta. SNI-03-6390-2011.

Badan Standardisasi Nasional. Tatacara Perancangan Sistem Ventilasi dan Pengondisian Udara pada Bangunan Gedung. Jakarta. SNI 03-6372-2001.

Brent Stephen. (2014). The impact of duct design on life cycle cost of the central reditential heating and air conditioning. Energy and Building. United State of America.

C.P. Arora. (2001). Refrigeration and Air Conditioning 2nd Ed. The McGraw-Hill Companies, Inc. United States of America.

Carrier Air Conditioning Company. (1965). Handbook of Air Conditioning System Design. The McGraw-Hill Companies, Inc. United States of America.

Indonesia (2002). Bangunan Gedung:Undang-Undang Nomor 28 Tahun 2002.

J.M. Loewen. (1992). Audits, Energy and Environment Division Lawrence Berkeley and Association of South East Nations. ASEAN-USAID Building Energy Conservation Project Final Report Volume III.

Jaesuk Park. (2013). Comparative analysis of the VRF system and conventional HVAC system focused on Life-Cycle Cost. Thesis. Georgia Institute of 
Technology. United State of America.

Lal Jayamaha. (2007). Energy-Efficient Building System. The McGraw-Hill Companies, Inc. United States of America.

Nation Institute of Standards and Technology. (1995). NIST Handbook 135 Life-Cycle Costing Manual For The Federal Energy Managemant Program. American Society of Heating, Ventilating, and Air Conditioning Engineers, Inc. United States of America.

Perusahaan Listrik Negara. (2017). Statistik PLN Tahun 2017.Jakarta.

Prof. Dr. Essam E. Khalil. (2007). Life Cycle Cost Analysis of Air-Conditioned Commercial Building in Egypt. Mechanical Power Engineering Department-Cairo University. Egypt.

R. Conry, L. Whedan, J. Ostman. (2002). Magnetic Bearing, Variable Speed Centrifugal Compression and Digital Control Applied in A Small Tonnage Refrigerant Compressor Design. Purdue University. United State of America.

Sen Huang. (2014). Optimization of the water-cooled chiller plant system operation. University of Miami. United State of America.

Shan K Wang. (2000). Handbook of Air Conditioning and Refrigeration. The McGraw-Hill Companies, Inc. United States of America.

Tolga N. Aynur. (2009). Variable refrigerant flow systems: A review. Energy and Building. United of Amirica.

Vera Gutul I, Iolanda Colda, Vera Gutul G, Liubovi Usturo. (2019). Comparative Analysis of Variable Refrigerant Flow Systems and Chiller-Fan Coil System For Office Building. Technical University of Moldova. Rumania.

William Goetzler. (2007). Variable Refrigerant Flow Systems. American Society of Heating, Ventilating, and Air Conditioning Engineers, Inc. United States of America.

William Parry Bahnfleth. (2006). Energy use and economic comparison of chilled-water pumping system alternatives. Pennsylvania State University. United State of America.

Yu, \& P.C.H and Chow (2001). Energy use in commecial building in Hongkong, Applied Energy.pp 243255.

Zhenjun Ma, Shengwei. (2008). Energy efficient control of variable speed pumps in complex building central air-conditioning systems. Energy and Buildings. United State of America. 